\title{
Faculty Who Inspire
}

\author{
Libby V. Morris
}

Published online: 1 June 2010

(C) Springer Science+Business Media, LLC 2010

At the end of each academic year, the University of Georgia (UGA), like countless other colleges and universities across the nation, celebrates the outstanding performance of faculty, staff, and students. Here at UGA the ceremonies of honorary societies and individual colleges and units began in March and concluded with graduation in May 2010. In mid-March the University of Georgia Research Foundation presented the $31^{\text {st }}$ annual research awards. An elaborate dinner launched the evening at which 19 faculty members and 5 graduate students received creative research awards, medals, and other named designations for their outstanding accomplishments in research. These kinds of events provoke me to thinking about the inspirational models we have around us in the academic mileau.

My good friend and colleague, historian James C. Cobb, received the Albert Christ-Janer Award. Professor Cobb is widely recognized as one of the foremost scholars of Southern history and culture. He has written more than 40 articles and 12 books, mostly about the impact of changing economic conditions on the South. Two of his books, Away Down South: A History of Southern Identity and The Most Southern Place on Earth, his book about the Mississippi Delta, are considered classics in the field. I point to Dr. Cobb's award because of the broad appeal of his work to academics and the public alike. The video summarizing Dr. Cobb's award may be seen at http://www.creativeresearch.uga.edu/index.

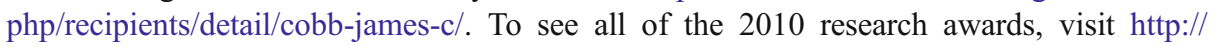
creativeresearch.uga.edu/. The award winners are inspiring faculty members.

Each year in early April, the University hosts Honors Day, a campus-wide event, which recognizes outstanding teachers, the top students, and exemplary faculty advisers and mentors. In 2010, 15 first honor graduates with perfect 4.0 averages were honored, along with other students who had graduated in the top 5\% of their colleges. With more than 6000 undergraduate and 2000 graduate degrees conferred annually, the competition for student awards is stiff; and the story is the same for faculty members, who number over 1800. Faculty awards at Honors Day include the Richard B. Russell Undergraduate Teaching awards for early career faculty and the naming of outstanding teachers in

L. V. Morris $(\bowtie)$

Institute of Higher Education, University of Georgia, 102 Meigs Hall, Athens, GA 30602-6772, USA

e-mail: lvmorris@uga.edu 
the individual colleges and schools. The University's highest recognition in teaching is the Josiah Meigs Distinguished Teaching Professor designation (http://provost.uga.edu/index. $\mathrm{php} /$ resources/awards/josiah-meigs-distinguished-teaching-professorships/). Meigs, the successor to Abraham Baldwin (UGA's first president), was the sole professor in 1801, and I assume faculty governance was less complicated then.

Meigs award winners receive a permanent increase in salary and a small discretionary fund each year. Juanita Johnson-Bailey, professor of education and interim director of the Institute for Women's Studies, was named a 2010 Meigs Distinguished Teaching Professor. I recommend the video on Professor Johnson-Bailey's award for both its professional and personal story. See the College of Education website (http://www.coe.uga.edu/) or http:// www.coe.uga.edu/media/JJB_high.m4v). It has been my privilege to know Professor Johnson-Bailey for many years; and, yes, she is inspirational on many levels. Professor Acosta-Alzuru in the Grady College of Journalism was also named a 2010 Meigs Distinguished Teaching Professor, and the video about her can be found at the following url $<$ http://www.grady.uga.edu/resources.php?al1=Resources\&al2=Grady+News\&page=news2. inc.php $\% 7 C I D=1102>$. Perhaps these videos, or similar records at your institutions, will inspire you as they did me.

This semester, I learned a great deal about faculty members at UGA who care deeply about teaching, who excel in the classroom, and who use their research to advance not only their disciplines and fields but also as a vehicle for instruction with both graduate students and undergraduates. These recognitions reminded me of how important it is to reward faculty for the critical roles they play every day in the lives of students. Awards are symbols of the campus culture, signifying not only individual attainment, but shared community values. In April 2010, the University of Georgia celebrated its $225^{\text {th }}$ anniversary as the oldest chartered public institution of higher education in the U.S. Our motto "to teach, to serve and to inquire into the nature of things" continues to reflect our value of teaching, service, and research.

Great universities and colleges value their faculty as their most important resource and the creators and keepers of campus culture. Public recognition and teaching awards, although highly important, are not sufficient to ensure quality in instruction, faculty satisfaction, and superior learning outcomes; rather, institutions must actively support faculty members so as to enhance their careers and to nurture the organization overall. Faculty development programs are essential to nurture faculty careers and to give faculty the tools and pedagogical knowledge needed for effective instruction. Across the career span, faculty members need mentors and programs and tools to reinvigorate research agendas and build new instructional skills to keep pace with educational and technological change.

For an overall understanding of the role of faculty development in campus culture and faculty lives, I recommend $A$ Guide to Faculty Development, $2^{\text {nd }}$ ed. (2010) edited by my associate editor, Dr. Kay Gillespie, and her colleague, Douglas Robertson. This book is a valuable resource on faculty development at the individual, program, and college level. Kay is a nationally recognized expert on faculty development, and I know you will find the text useful to planning and reflecting on faculty development on your campus. I am lucky to have Kay as friend, colleague and "editor in action" of Innovative Higher Education.

We can and should work together-individually and collectively-to recognize and express appreciation for those who inspire us and to nurture ourselves in all possible ways. 